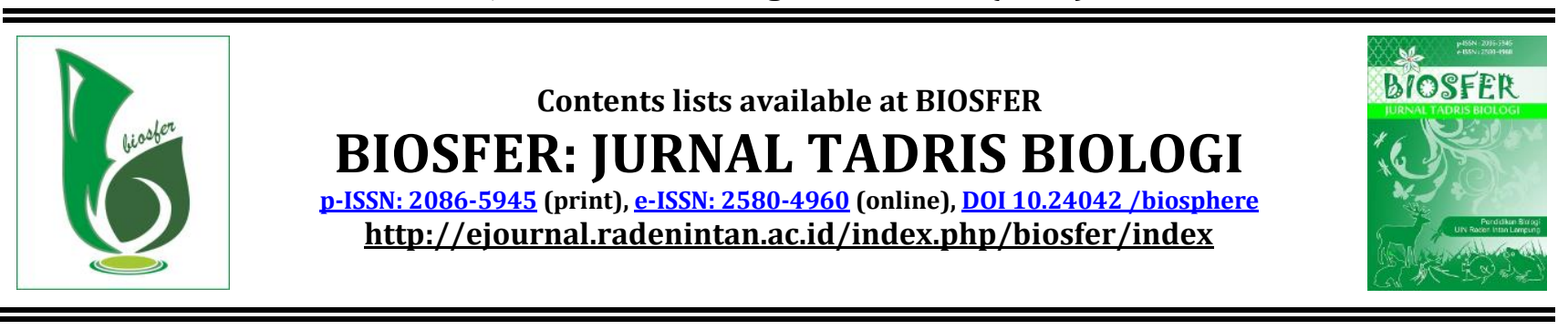

\title{
Developing Islamic-Based Botanical Encyclopedia as a Learning Resource
}

\author{
Elfrida Nurutstsany ${ }^{1 *}$, Saifullah Hidayat ${ }^{2}$, Nur Hayati ${ }^{3}$ \\ 1, 2, 3 UIN Walisongo Semarang, Indonesia
}

\section{ARTICLE INFO}

\section{Article History}

Received : 09-07-2020

Accepted : 09-10-2020

Published : 30-12-2020

\section{Keywords:}

Botanical Encyclopedia;

Integrated Islam;

Learning Resources

*Correspondence Address:

elfridatsany@gmail.com

\begin{abstract}
Learning resources need to be developed based on current developments. The purpose of this research was to develop an Islamicbased Botanical Encyclopedia and test its quality. The method used to develop the encyclopedia was Research and Development (R\&D) with the 4D model (Design, Define, Develop, and Disseminate) proposed by Thiagarajan in 1974 as the development model. The research instrument had been validated by the material, media, and integration experts. The average percentage of the validation result was $88 \%$ (a very valid category). The small-scale trial obtained a percentage of $89 \%$ (very valid), and the large-scale trial obtained a percentage of $85 \%$ (very feasible category). The results indicated that the developed Islamicbased Botanical encyclopedia could be used as a resource for independent learning.
\end{abstract}

\section{Pengembangan Ensiklopedia Ilustrasi Botani Berintegrasi Islam Sebagai Sumber Belajar}

\begin{abstract}
Abstrak: Tujuan dari pengembangan penelitian ini adalah untuk mengembangkan ensiklopedia dan menguji kualitas ensiklopedia. Metode yang digunakan untuk mengembangkan ensiklopedia adalah Research and Development (R\&D) dengan model 4D (Design, Define, Develop, Disseminate) yang dikembangkan oleh Thiagarajan tahun 1974. Instrumen pengumpulan data menggunakan lembar validasi oleh ahli materi, ahli media, ahli integrasi, guru biologi, peer reviewer, dan peserta didik Kelas XI SMA. Rata-rata persentase uji validitas adalah 88\% yang tergolong dalam kategori sangat valid. Uji coba skala kecil mendapatkan persentase sebesar 89\% yang menunjukkan sangat valid sehingga dapat dilanjutkan pada uji coba skala lebih luas. Uji skala lebih luas menunjukkan persentase sebesar 85\% yang termasuk dalam kategori sangat layak. Hal tersebut menunjukkan bahwa Ensiklopedia Ilustrasi Botani layak digunakan sebagai sumber belajar mandiri.
\end{abstract}

\section{INTRODUCTION}

Plants' structure and tissue belong to organs' function (Baidlowi et al., 2020;
Widyarsih et al., Nd). The observation of outer morphology and inner morphology in plants is a source of knowledge (Oratmangun et al., 2017; Sari, 2017; Utari et 
al., 2017). Also, learning experiences are needed to understand science and biology (Leksono et al., 2013; Mumpuni, 2013; Suryaningsih, 2017). Practicum activities in the surrounding environment positively influence students in obtaining their longterm knowledge and understanding (Aswita, 2017; Mahampang, 2017; Novitasari \& Budijastuti, nd).

The information needed by students can be fulfilled through media and learning resources (Andriani, 2016; Anshori, 2018; Hardianto, 2007; Sugianto et al., 2013). Adequate learning resources are an instrumental sub-component of education (FAJRIR RAHMAN, 2013; Yunarko et al., 2015). Learning sources come from anywhere, and their existence can facilitate learning activities in various forms (Surani, 2019). Abundant learning resources are an interesting learning resource (Kristianto, 2016; Ma'rifah, 2020; Nurhayati, 2020; Wardinur \& Mutawally, 2019). Arranging the encyclopedia in alphabetical order makes it easier for readers to find information (Pratama \& Marlini, 2018). The encyclopedia contains information accompanied by pictures.

The encyclopedia is one of the most interesting learning resources. Therefore, its development is needed to become an attractive learning resource for students (Bramasta \& Irawan, 2018; Saputra \& Ekawati, 2017). Illustrated botanical encyclopedia is developed as a learning resource that emphasizes scientific recording and botanical accuracy to identify plants.

Education should be a balance between intellectual, emotional, and spiritual intelligence. Spirituality gives great meaning to the nation's life to always provide the best for the nation (Murdiono, 2010). Biology as a science contains values that can be applied contextually so that its material can present Islamic values to students.

This research is in line with previous research on developing botanical illustrations as a learning resource (Hanif et al., 2016; Nur, 2016; Pertiwi \& Susilo, 2014). Other studies integrate Islamic education and mathematics modules development (Arifudin, 2017; Ekawati et al., 2019). Also, research measures learning resources but with different media and materials (Kristianto, 2016; Nur, 2016; Nurhayati, 2020). Therefore, the novelty of this research is the integration between Islamic values and the learning resources. Each plant illustration is equipped with a description of the plant's parts, the classification, and the characteristics of the plant. The development of an illustrated botanical encyclopedia is expected to meet students' needs and improve students' scientific skills.

\section{METHOD}

This study employed the 4-D development model (Define, Design, Develop, and Disseminate) developed by Thiagarajan. The researchers focused only on three stages, namely Define, Design, and Develop. The Disseminate step can be refined in further research. The Define stage covered the front-end analysis, task analysis, concept analysis, and specific instructional objectives analysis. The Design stage consisted of designing, compiling, and printing the encyclopedia. The Develop stage covered the expert validation performed by material experts, media experts, integration experts, biology teachers, and peer reviewers. The trials consisted of a smallscale trial and a large-scale trial. The research framework is displayed as follows. 


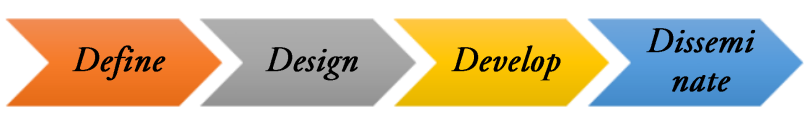

Picture 1. Research Framework of the 4-D Model

The research subjects were the eleventh-grade students of senior high school selected using probability random sampling techniques. The small-scale trial was implemented on nine students, and the large-scale trial was implemented on 48 students. The researchers' data collection techniques were interview, observation, specimen collection, documentation, illustration, and questionnaire.

\section{RESULT AND DISCUSSION}

The validation was performed by experts, biology teachers, and peer reviewers. The material expert was a Plant Systematics Course lecturer at UIN Walisongo Semarang (Rita Ariyana Nur Khasanah, S.Pd., M.Sc). The role of material experts is providing corrections to the information in the encyclopedia. The material expert validation aspects were material coverage, accuracy, activities, the material to develop thinking skills, language use, terms or symbols, and evaluation. The media experts focused on the layout and illustration of the encyclopedia. Nisa Rasyida, M.Pd., a biology lecturer at UIN Walisongo Semarang, was selected as the validator. The media validation aspects include general presentation organization, the usefulness of presentation, general appearance, and completeness of the encyclopedia. The integration validator was Luthfi Rahman, M. SI., MA, a lecturer at the Faculty of Ushuludin and Humaniora of UIN Walisongo Semarang. Integration experts focused on the scientific linkages between the verseization of Islamic values and humanization of Islamic science. A biology teacher, Khamdanah, SP, S.Pd, was selected as the validator regarding the encyclopedia's accuracy. Biology teacher validation aspects included material coverage, completeness of the content, presentation components, layout, and language use. Peer reviewers strengthen the data. Peer reviewers' qualifications were biology education students who have taken Botanical Science courses. The peer reviewer validation aspects consisted of material coverage, presentation, language, and presentation suitability.

The validators provided assessment through questionnaires. The percentage of data from the encyclopedia's assessment validation results is presented in Figure 2.

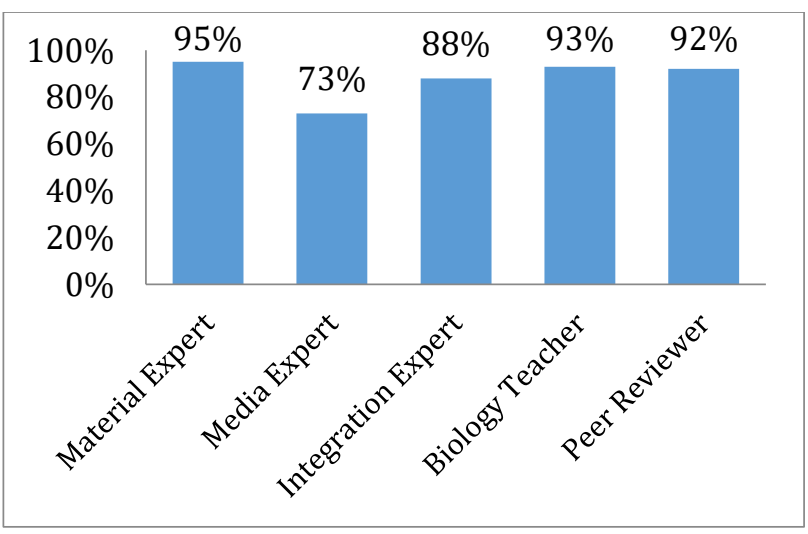

Figure 2. The Percentage of Validation Results

The percentage of validation results showed that the encyclopedia was very valid to be used as a learning resource. The percentage result of media experts was $73 \%$, indicating that the encyclopedia was valid to be used as a learning resource, although a small-scale revision was required. The inputs and suggestions were used to revise the encyclopedia to continue to the field testing stage.

The revised encyclopedia was then tested on nine students. The small-scale trial aspects included material coverage, presentation, language, and suitability. The 
percentages obtained in this stage are presented in Figure 3.

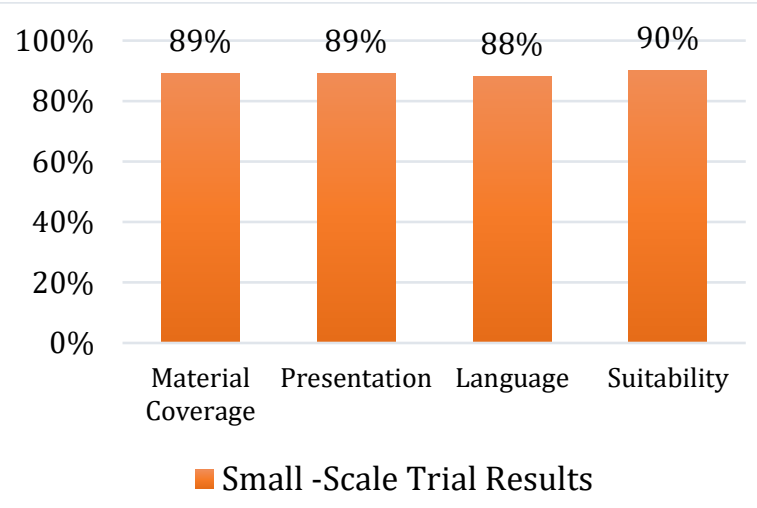

Figure 3. Small-scale Trial Results

The average percentage of the smallscale trial was $89 \%$. The descriptive analysis of these percentages showed that the encyclopedia was very valid to be used as a learning resource without revision. These results provided the basis for researchers to test the encyclopedia on the large-scale trial.

A large-scale trial was carried out to determine the feasibility of the encyclopedia. The assessment was carried out by 48 eleventh-grade students of senior high school through questionnaires. The aspects of feasibility were material coverage, presentation, language, and suitability of the presentation. The results of the large-scale trial are presented in Figure 4.

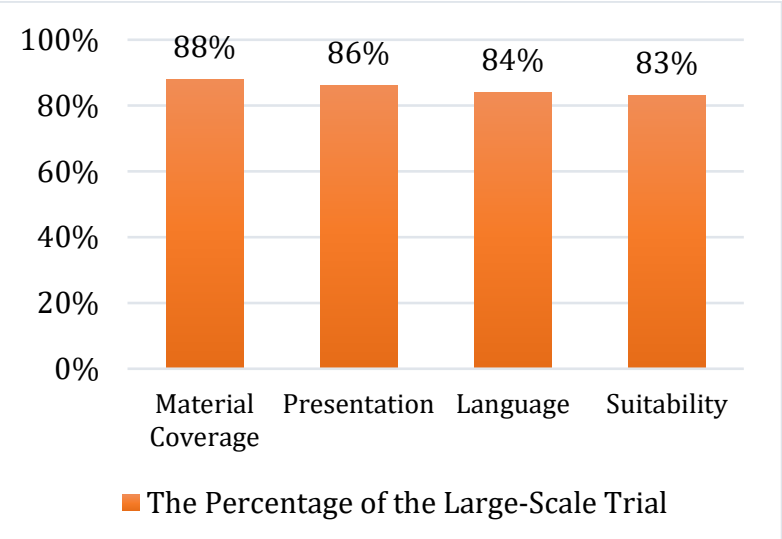

Figure 4. The Percentage of the Large-Scale Trial
The average percentage of the largescale trial was $85 \%$ in the very feasible category. The descriptive analysis of these percentages showed that the developed encyclopedia was very suitable to be used as a learning resource. Here is the display sample of the encyclopedia:

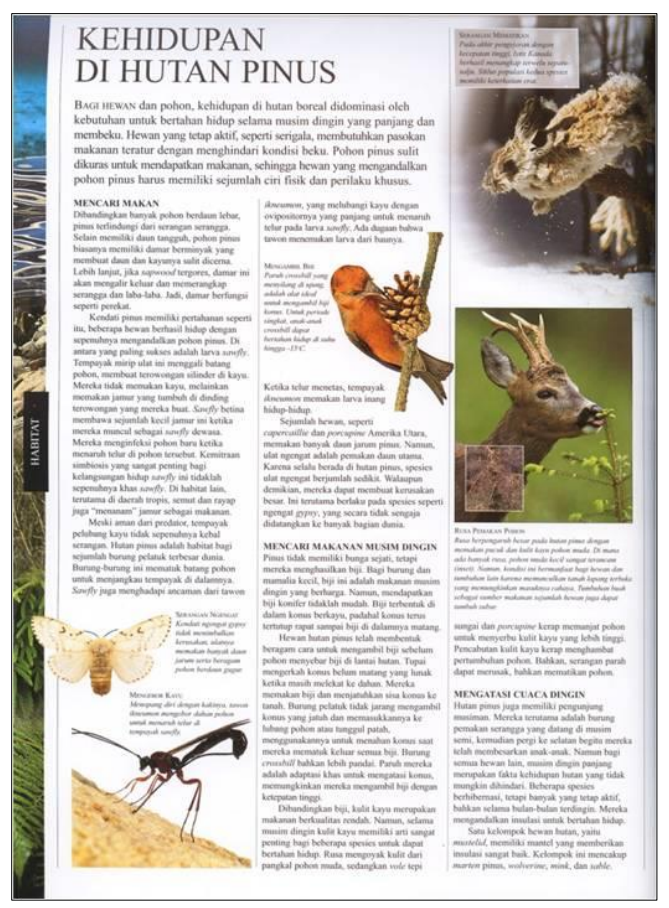

Figure 5. The Display of the Encyclopedia

The encyclopedia was constructed based on the identification of the research results by taking pictures of each species. The materials were compiled and designed using an application to develop an attractive encyclopedia arrangement. The media expert then validated the revised encyclopedia. After meeting the valid assessment criteria, the encyclopedia was printed as the final product.

The results obtained by researchers are in line with previous studies using encyclopedias. Encyclopedias effectively improve learning achievement (Hanif et al., 2016). Nur (Nur, 2016) discovers that learning resources can improve memory, basic language skills, and enrichment activities. 


\section{CONCLUSION}

This research's final product was an Illustrated Botanical Encyclopedia that can be used as a learning resource. The percentage of the feasibility test was included in the very feasible category. The results were based on the assessments performed by media experts, material experts, integration experts, biology teachers, peer reviewers, and students. It is suggested to improve this research further so that this research can be used as a reference for further research.

\section{REFERENCES}

Andriani, T. (2016). Information and communication technology-based learning system. Socio-Culture, 12 (1), 117-126.

Anshori, S. (2018). Utilization of Information and Communication Technology as Learning Media. Civic-Culture: Journal of Civic Education and Socio-Cultural Studies, 2 (1).

Arifudin, I. (2017). Integration of Science and Religion and Its Implications for Islamic Education. Educasia Islamika, 161-180.

Aswita, D. (2017). Identification of problems faced by biology teachers in implementing learning on ecosystem material. BIOTICS: Scientific Journal of Biology, Technology, and Education, 3 (1), 63-68.

Baidlowi, MH, Sunarmi, S., \& Sulisetijono, S. (2020). Development Of Higher Order Thinking Skills (Hots) Problem Essay Instruments (Hots) Network Structure Materials And Organ Functions In Growth Class XI SMAN 1 Tumpang. Journal of Biological Education, 10 (2), $57-65$.
Bramasta, D., \& Irawan, D. (2018). Distribution of Facilities and Infrastructure for Elementary School Libraries based on Geographic Information Systems. EDUCATION KHAZANAH, 11 (1).

Ekawati, T., Anggoro, BS, \& Komarudin, K. (2019). Development of a Mathematics Learning Module in Integrated Statistics Material of Islamic Values. Axiom: Journal of Mathematics Education Study Program, 8 (1), 184192.

FAJRIR RAHMAN, N. (2013). Website Media Development in Maintaining Multimedia Equipment Subjects Camera Material for Class X Multimedia Students at SMKN I Surabaya. Journal of Educational Technology Students, 4 (3).

Hanif, H., Ibrohim, I., \& Rohman, F. (2016). Development of biology learning tools for Plantae material based on guided inquiry integrated with Islamic values improves high school students' conceptual understanding. Journal of Education: Theory, Research, and Development, 1 (11), 2163-2171.

Hardianto, D. (2007). Designing Computers as Alternative Media for Independent Learning. Learning Scientific Magazine, 3 (2).

Kristianto, H. (2016). The Relationship On The Utilization Of Newspapers As Learning Resources In The Civil Study Materials Of Democracy To Learning Motivation Of Class XI Students At SMA Negeri 1 Geger Madiun. Moral and Citizenship Study, 4 (3).

Leksono, SM, Rustaman, N., \& Redjeki, S. (2013). The professional ability of biology teachers in understanding and designing biodiversity conservation 
learning models in high school. Cakrawala Pendidikan Journal, 3 (3).

Mahampang, L. (2017). The importance of a process skills approaches to science learning in Madrasahs. ELEMENTARY: Islamic Teacher Journal, 4 (1).

Ma'rifah, FU (2020). Utilization of Salted Fish in Indonesian Language Learning in SD / MI. Madani: Indonesian Journal of Civil Society, 2 (2), 15-21.

Mumpuni, KE (2013). The potential for character-based local excellence education in biology learning in Indonesia. Proceeding Biology Education Conference: Biology, Science, Environmental, and Learning, 10 (2), 73-79.

Murdiono, M. (2010). The strategy of internalizing religious moral values in the learning process in higher education. Journal of Cakrawala Pendidikan, 1 (3).

Novitasari, FD, \& Budijastuti, W. (nd). Validity of Student Activity Sheets (LKPD) Based on Guided Inquiry on Environmental Change Material for Practicing Process Skills of Class X SMA Students. Periodic Scientific Biology Education (BioEdu), 10 (1), 113-125.

Nur, FM (2016). Utilization of learning resources in fifth grade elementary school science learning on living things and life processes. JESBIO: Journal of Biological Science and Education, 1 (1).

Nurhayati, USA (2020). Utilization Of Digital Content Of Learning Source Center (PSB) IN Pioneering School Of Psb Device Receivers. Journal of Education, 21 (2), 77-93.
Oratmangun, KM, Pandiangan, D., \& Kandou, FE (2017). Description of Types of Contaminants from Callus Cultures of Catharanthus roseus (L.) G. Donnaman. Journal of Mathematics and Natural Sciences, 6 (1), 47-52.

Pertiwi, AD, \& Susilo, BE (2014). Analysis of Mathematical Communication Ability through Learning Model 4K Based on Personality Types of Class VII Students. Kreano, Journal of CreativeInnovative Mathematics, 5 (2), 195204.

Pratama, E., \& Marlini, M. (2018). Writing Thesis Annotated Bibliography of 2015-2018 Accounting Thesis at AKBP-STIE "KBP" Padang Library. Library and Archives Information Science, 7 (2), 18-25.

Saputra, NE, \& Ekawati, YN (2017). Traditional games as an effort to improve children's basic abilities. Journal of Psychology Jambi, 2 (2), 4753.

Sari, V. (2017). Genetic diversity of shallots (Allium cepa L.) based on morphological markers and ISSR. Indonesian Journal of Agronomy (Indonesian Journal of Agronomy), 45 (2), 175-181.

Sugianto, D., Abdullah, AG, Elvyanti, S., \& Muladi, Y. (2013). Virtual module: Multimedia flipbook, basic digital technique. Innovation of Vocational Technology Education, 9 (2).

Surani, D. (2019). Literature study: The role of educational technologists in education 4.0. Proceedings of the FKIP National Education Seminar, 2 (1), 456-469.

Suryaningsih, Y. (2017). Practical based learning as a means for students to 
practice applying science process skills in biology material. BIO EDUCATIO: (The Journal of Science and Biology Education), 2 (2).

Utari, DS, Kardhinata, EH, \& Damanik, RI (2017). Morphological Character Analysis and Relationship of Sweet Potato (Ipomoea Batatasl.) Plants in the Highlands and Lowlands of North Sumatra: Analysis of the morphological characteristic and genetic relationship of sweet potato (Ipomoea batatas L.) in the Highlands and Lowlands of North Sumatra. Online Journal of Agroecotechnology, 5 (4), 870-881.

Wardinur, W., \& Mutawally, F. (2019). Teacher Competency Improvement through Training on the Use of Technology as a Learning Support Media at MAN 1 Pidie. USK Journal of Sociology (Media for Thought \& Applications), 13 (2), 167-182.

Widyarsih, N., Daningsih, E., \& Marlina, R. (nd). Feasibility Of Powerpoint Based On Flash Structure And Network Function On Plants In Class XI SMA. Journal of Equatorial Education and Learning, 7 (12).

Yunarko, M., Suntoro, I., \& Yulianti, D. (2015). Evaluation of Library Utilization as Learning Resource Center. Journal of Educational Communication Information Technology (Old), 3 (3). 
Biosfer, 11 (2) (2020) 151 - 158

Elfrida Nurutstsany, Saifullah Hidayat, Nur Hayati 